\title{
Analysis of mechanical and microstructural properties of high performance concretes containing nanosilica and silica fume
}

Jéssica Zamboni Schiavon ${ }^{1}$, Pietra Moraes Borges ${ }^{1}$, Sérgio Roberto da Silva ${ }^{1}$, Jairo José de Oliveira Andrade ${ }^{1}$

\footnotetext{
${ }^{1}$ Programa de Pós-Graduação em Engenharia e Tecnologia de Materiais, PGETEMA/PUCRS, Av. Ipiranga, 6681, Prédio 30, Parternon, Porto Alegre, RS, Brasil.

e-mails: jessica.squiavon@acad.pucrs.br, pietra.borges@acad.pucrs.br, sergio.roberto@acad.pucrs.br, jairo.andrade@pucrs.br
}

\begin{abstract}
The use of nanomaterials in concrete has shown promise, and the use of several types in cementitious compounds has been found to guarantee greater physical-mechanical properties and improvements in microstructure. The use of mineral admixtures, such as silica fume, ensures the improvement of the interfacial transition zone (ITZ) between aggregate and paste in high-performance concrete (HPC). Thus, this work evaluates the performance of superplasticizer additive with colloidal nanosilica suspension and slurried silica fume with HPC and its macro- and micro-structural properties. The mechanical (i.e., compressive strength and elastic modulus) and microstructural properties via (scanning electron microscopy and X-ray micro tomography) of concretes with 1.5 and 3\% nanosilica and 5 and $10 \%$ silica fume included in the evaluation methods in this study. The results indicate that, with the use of mineral admixtures, the compressive strength and elastic modulus of concrete increased significantly. The concrete with the use of $10 \%$ silica fume and $3 \%$ nanosilica resulted in a showed an increased strength over $75 \%$ at 28 days. Besides that, for same $\mathrm{w} / \mathrm{b}=0.35$ the elastic modulus increased by $36 \%$ compared with the reference concrete. The microstructural investigations show that the nanosilica and silica fume led to a densification of microstructure, which is responsible for the improvement of HPC performance.
\end{abstract}

Keywords: high performance concrete, silica fume, nanosilica, mechanical properties, microstructure.

\section{INTRODUCTION}

Concrete represents one of the most widely used construction materials worldwide by volume. Efforts are needed to design and develop more ecologically friendly concrete with improved performance in strength and durability [1]. The high-performance concrete (HPC) has become vital for the construction of skyscrapers from a structural and economical point of view. Higher mechanical strength is crucial to carry loads and reduce the cross-sections of vertical load-bearing elements (columns and walls), while a high modulus of elasticity is necessary to limit deflections and wind sway [2]. Thus, HPC has become a much stronger competitor for super tall buildings, compared to structural steel. The super-tall buildings in the future will be made of HPC, with a steel or composite spire at the top [2]. High-performance concrete consists of a mixture with supplementary materials, superplasticizer admixture and a low ratio water/binder. These materials make the cast-in-place of concrete easier by reducing the amount of transverse reinforcement, improving performance, attenuating damage in critical regions, minimizing residual deformations and reducing repair costs in structures located in seismic areas [3].

The potential of using pozzolanic materials has been explored, through the use of slag, palm oil ash, fly ash, silica fume, metakaolin and rice husk ash [4]. The supplementary cementitious materials (SCMs) used by the cement industry are limestone and industrial by-products, such as fly ash from coal plants, blast furnace slag from pig iron production and silica fume from the Ferro-silicon industry. In addition, natural pozzolans and thermally activated clay minerals (for example, metakaolin) are used, which, together with industrial by-products, characterized by high levels of silica or silica and alumina [5]. Fly ash and metakaolin demonstrated efficiency in this regard, with the filling of smaller pores of the concrete reported due to the increase in pozzolanic reactions [6]. The combined use of SCMs in concrete contributes to an increase in the generation of CSH gel and consequently the densification of the microstructure. The presence of SCMs in concrete provides greater production of $\mathrm{C}-\mathrm{S}-\mathrm{H}$ and, consequently, improves the physical-mechanical properties, which 
is important for the improvement of high-performance concrete (HPC) [7-9]. The use of fly ash, for example, the compressive strength ranges from 45 to $67 \mathrm{MPa}$, favoring its contribution to structural concrete [10]. As a by-product of the manufacture of silicon and ferrosilicon alloys, silica fume contains more than $90 \% \mathrm{SiO}_{2}$ and is present in spherical shape with average diameters about 100 times smaller than cement particles. The high specific surface area of silica fume is 10 to 20 times greater than that of other pozzolanic materials [1]. Silica fume is advantageous for use in concrete, mainly due to its high specific surface and the amount of amorphous silica, which increases the formation of hydrated products at an early age [9]. The addition of silica fume influences the thickness of the transition zone of the concrete cement paste, and the degree of orientation of the $\mathrm{CH}$ crystals, therefore, the mechanical properties and durability are improved [11]. ANWAR and EMARAH [12] demonstrated that the use of silica fume could decrease the carbonation of cement paste products and increase resistance to attack by chlorides, improving their durability, due to the pozzolanic effects.

In the same way, the addition of silica fume improved the microstructure of all the specimens, irrespective of the aggregate (granite and quartzite) types in concrete [13]. The increase in strength can be observed in the replacement of cement by silica fume up to $20 \%$, and from 10 to $15 \%$ of silica fume provides the optimum result. In addition, the resistance increases with increasing aging ages compared to the reference mixture. The incorporation of silica by up to $25 \%$ provides an improvement in the durability properties of concrete while being affected if the silica fume content exceeds $25 \%$ [14]. The high specific surface of silica fume makes it difficult to handle the material, in addition to worsening the workability of cementitious materials, unless it is made in the form of paste. Despite this, fine particles fill the spaces between the cement paste, thus producing a denser paste, decreasing the permeability and porosity of the composite [15].

The application of nanotechnology in cement-based materials is still under research. The results of experimental tests of concrete samples with nanomaterials have demonstrated that they can increase the compressive strength and durability of concretes [16]. The nano $(\mathrm{nm})$ size of the nanoparticles produces a filling effect of cement pastes compared to materials on a micro $(\mu)$ scale [7]. The most favorable nanoparticles for use in cementitious materials are nano $\left(\mathrm{SiO}_{2}, \mathrm{Al}_{2} \mathrm{O}_{3}, \mathrm{Fe}_{2} \mathrm{O}_{3}, \mathrm{TiO}_{2}\right.$, although there are studies containing nano $\left(\mathrm{ZrO}_{2}\right.$ and $\left.\mathrm{ZnO}_{2}\right)$. However, nanomaterials such as nanosilica, carbon nanotube and graphene oxide, have been used as nano-reinforcement to improve its properties (compressive strength, microstructure and durability) together with supplementary cementitious materials such as fly ash [17]. According to SAID et al. [18] nanosilica can be found as a colloidal suspension and compacted dry grains. The incorporation of nanosilica in cement solutions is more effective, depending on the adequate dispersion of particles in the concrete mass, which reduces agglomeration and is preferable for practical purposes [18].

XU, WANG and ZUO [19] investigated the relationship between the macro and microscale properties of concretes with the addition of $1 \%$ nanosilica. Their results showed an increase in compressive strength and elastic modulus after 3 days. According to NAZERIGIVI and NAJIGIVI [20] the cement paste could be benefited with nanosilica nanoparticles up to a maximum level of $2.0 \%$ and with particles of $15 \mathrm{~nm}$; and another $1.5 \%$ with particles with $80 \mathrm{~nm}$. LI and GAO [21] reported that the ideal nanosilica content in concrete is $1 \%$, while NILI and EHSANI [22] found that the addition of 5\% nanosilica increased the compressive strength of concrete, and densified the microstructure of the concrete. According to WANG et al. [23] the mechanical properties of cement pastes were improved with the addition of $3 \%$ nano- $-\mathrm{SiO}_{2}$, the compressive strength at three days increased by $33.2 \%$ and at 28 days it increased by $18.5 \%$.

However, the difficulty of dispersing nanomaterials adversely affects the performance of cementitious materials and remains unresolved. FENG et al. [24] used polycarboxylate superplasticizer and nano- $\mathrm{SiO}_{2}$ particles for use in cementitious materials. From a content greater than $0.5 \%$, the nanosilica sample and the reference sample have very similar volume fractions of gel pores and medium capillary pores. This factor was explained by the possible agglomeration of the nanosilica and by the compact gel; structure of the hydration products, the diffusion of dehydrates is blocked and, therefore, produces a more porous structure [24]. The microstructure of mixtures containing nanosilica is characterized by phases containing calcium hydroxide, etringite, AFm and C-S-H, identified [25].

High-performance concrete is very important nowadays, as there are several benefits associated (high compressive strength, besides being useful for environments that need concrete with great durability). However, the design of the compound and the combined use of mineral additions with chemical additives are not yet fully understood [10]. Due to the relevance of high-performance concrete, which is significant for constructions that require extremely efficient structural materials, this work seeks to use a mineral addition combined with a nanomaterial. This study demonstrates the efficiency of silica fume in suspension, as well as the polycarboxylate superplasticizer with nanosilica in order to evaluate the efficiency of materials in mechanical properties (compressive strength and elastic modulus), porosity via $\mathrm{x}$-ray micro tomography and the effect of 
densification microstructure via scanning electron microscopy. Thus, this investigation contributes to the understanding of the effect of nanosilica and silica fume on the macro and microscale properties of highperformance concrete considering the synergistic benefit.

\section{MATERIALS AND EXPERIMENTAL PROCEDURES}

\subsection{Materials}

Brazilian high early strength Portland cement, similar to ASTM Type C 150 III [26], was used in concrete mixtures, presenting a specific surface, density, and compressive strength at 28 days equal to $1425 \mathrm{~cm}^{2} / \mathrm{g}$, $3.05 \mathrm{~g} / \mathrm{cm} 3$, and 51.3 MPa, respectively. Silica fume was used composed of silica dispersed in an aqueous solution, containing a solids content of $50 \%$ and $50 \%$ water. This water amount from silica fume needs to be discounted later from the water of the mixtures made. Slurried silica fume presents a BET surface area equal to $18.42 \mathrm{~m}^{2} / \mathrm{g}$, a spherical shape and an average particle size of $0.3 \mu \mathrm{m}$. In Table 1 , its properties are presented according to the manufacturer. In Fig. 1 is presented the morphology of silica fume particles and their main elements obtained by EDS analysis.

Table 1: Properties of silica fume.

\begin{tabular}{c|c}
\hline PROPERTY & RESULT \\
\hline Appearance & Dark gray liquid \\
\hline $\mathrm{SiO}_{2}, \%$ & 94.5 \\
\hline Loss of ignition, $\%$ & 2.2 \\
\hline Alkaline equivalent $\mathrm{Na}_{2} \mathrm{O}, \%$ & 0.2 \\
\hline Solid content, $\%$ & 49 \\
\hline Sieve $45 \mu \mathrm{m}(325 \mathrm{Mesh}), \%$ & 0.2 \\
\hline Bulk density, $\left(\mathrm{g} / \mathrm{cm}^{3}\right)$ & 1.38 \\
\hline Viscosity, $(\mathrm{s})$ & 7.1 \\
\hline $\mathrm{pH}$ & 7.1 \\
\hline
\end{tabular}
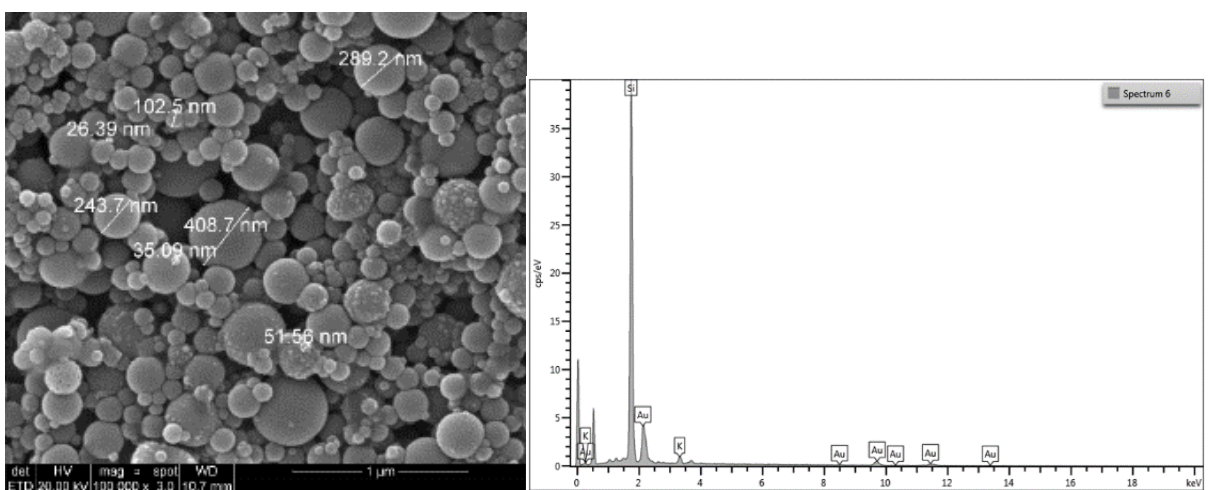

Figure 1: SEM image (a) and EDS spectrum (b) of silica fume particles.

The other product is a polycarboxylate based superplasticizer additive and is industrially incorporated in to colloidal nanosilica suspension. This stabilized nanosilica has BET surface area characterization equal to 250 $\mathrm{m}^{2} / \mathrm{g}$, an average particle size of $13 \mathrm{~nm}$ and bulk density $1.06 \mathrm{~g} / \mathrm{cm}^{3}$. For concretes that did not contain stabilized nanosilica, a polycarboxylate-based superplasticizer content bulk density $1.1 \mathrm{~g} / \mathrm{cm}^{3}$ was used to maintain adequate workability. The fine aggregate used was river sand, and the coarse aggregate was of basaltic origin. Their characteristics are presented in Table 2. 
Table 2: Characteristics of the aggregates.

\begin{tabular}{l|c|c|c|c}
\hline TEST & $\begin{array}{c}\text { FINE } \\
\text { AGGREGATE }\end{array}$ & $\begin{array}{c}\text { BRAZILIAN } \\
\text { STANDARD }\end{array}$ & $\begin{array}{c}\text { COARSE } \\
\text { AGGREGATE }\end{array}$ & $\begin{array}{c}\text { BRAZILIAN } \\
\text { STANDARD }\end{array}$ \\
\hline $\begin{array}{l}\text { Apparent specific gravity } \\
\left(\mathrm{g} / \mathrm{cm}^{2}\right)\end{array}$ & 2.60 & $\begin{array}{c}\text { NBR NM 52 } \\
{[27]}\end{array}$ & 2.92 & NBR NM 52 [27] \\
\hline Bulk density $\left(\mathrm{g} / \mathrm{cm}^{3}\right)$ & 1.50 & $\begin{array}{c}\text { NBR NM 45 } \\
{[28]}\end{array}$ & 1.54 & NBR NM 45 [28] \\
\cline { 1 - 2 } Fineness modulus & 2.56 & \multirow{2}{*}{$\begin{array}{c}\text { NBR NM 248 } \\
{[29]}\end{array}$} & 7.01 & \multirow{2}{*}{ NBR NM 248 [29] } \\
\cline { 1 - 2 } Maximum size $(\mathrm{mm})$ & 4.75 & & & \\
\hline
\end{tabular}

\subsection{Experimental Procedures}

Several proportioned mixes were designed to evaluate the effects of silica fume and nanosilica in three concrete classes, depending on their water/binder (w/b) ratio: 0.25 (HPC 1), 0.30 (HPC 2), and 0.35 (HPC 3). Two levels of nanosilica (1.5 and 3\%) were used in concretes, similar to those used in previous studies whose levels were $2.0 \%[30,31]$. The silica fume were used with two levels (5 and 10\%). According to MEHTA and ASHISH [14] the silica fume improves the hydration of the cement paste, but as the percentage of silica substitution grows, the workability of the concrete mixture decreases due to the increase in the surface area of the silica. The increase in resistance can be observed in the use of silica fume by up to $20 \%$. Considering the production of all combinations, a complete experiment would ordinarily be necessary for all 27 -mix proportions. Before the execution of each mixture, a manual homogenization was carried out to disperse the silica in the aqueous suspension. To optimize the amount of concrete mixtures, a fractional factorial project was used, given that only some of the total amount of tests would be performed. Many researchers have used fractional factorial design [32, 33]. The mix-proportioning method proposed by AÏTCIN [34], specifically developed for high-performance concretes, was used. The mix design used is presented in Table 3, Due the large number of mixtures and each of them uses a different parameter, in order to identify the behavior of each material (nanosilica and silica fume) isolated mixtures were performed. The workability was varied due to the other factors were fixed in the mixtures such as $w / b$ ratio and additive content.

Table 3: Characteristics of the aggregates.

\begin{tabular}{|c|c|c|c|c|c|c|c|c|c|c|}
\hline \multirow[b]{2}{*}{ Mix design } & \multirow[b]{2}{*}{$\mathbf{w} / \mathbf{b}$} & \multirow[b]{2}{*}{$\begin{array}{l}\text { SF } \\
(\%)\end{array}$} & \multirow[b]{2}{*}{$\begin{array}{l}\text { NS } \\
(\%)\end{array}$} & \multicolumn{5}{|c|}{ CONTENT $\left(\mathrm{kg} / \mathrm{m}^{3}\right)$} & \multirow[b]{2}{*}{$\begin{array}{l}\text { SP } \\
(\%)\end{array}$} & \multirow[b]{2}{*}{$\begin{array}{l}\text { SLUM } \\
\text { P } \\
(\mathrm{mm})\end{array}$} \\
\hline & & & & $\begin{array}{c}\text { CE- } \\
\text { MEN } \\
T\end{array}$ & $\begin{array}{l}\text { SILICA } \\
\text { FUME }\end{array}$ & $\begin{array}{l}\text { NANO- } \\
\text { SILICA }\end{array}$ & $\begin{array}{c}\text { FINE } \\
\text { AG- } \\
\text { GRE- } \\
\text { GATE }\end{array}$ & $\begin{array}{c}\text { COAR } \\
\text { SE } \\
\text { AG- } \\
\text { GRE- } \\
\text { GATE }\end{array}$ & & \\
\hline HPC1-SF0-NS0 & 0.25 & 0 & 0 & 520 & 0 & 0 & 874 & 989 & 2 & 225 \\
\hline HPC1-SF10-NS0 & 0.25 & 10 & 0 & 468 & 52 & 0 & 821 & 989 & 2 & 170 \\
\hline HPC1-SF5-NS1.5 & 0.25 & 5 & 1.5 & 494 & 26 & 7 & 854 & 989 & 0 & 180 \\
\hline HPC1-SF0-NS3 & 0.25 & 0 & 3 & 520 & 0 & 16 & 876 & 989 & 0 & 205 \\
\hline HPC1-SF10-NS3 & 0.25 & 10 & 3 & 468 & 52 & 14 & 822 & 989 & 0 & 210 \\
\hline HPC2-SF5-NS0 & 0.3 & 5 & 0 & 412 & 22 & 0 & 926 & 989 & 2 & 140 \\
\hline HPC2-SF0-NS1.5 & 0.3 & 0 & 1.5 & 433 & 0 & 7 & 954 & 989 & 0 & 195 \\
\hline HPC2-SF5-NS1.5 & 0.3 & 5 & 1.5 & 412 & 22 & 6.26 & 931 & 989 & 0 & 150 \\
\hline $\begin{array}{l}\text { HPC2-SF10- } \\
\text { NS1.5 }\end{array}$ & 0.3 & 10 & 1.5 & 390 & 43 & 5.84 & 909 & 989 & 0 & 200 \\
\hline HPC2-SF5-NS3 & 0.3 & 5 & 3 & 412 & 22 & 12 & 927 & 989 & 0 & 215 \\
\hline HPC3-SF0-NS0 & 0.35 & 0 & 0 & 371 & 0 & 0 & 1001 & 989 & 2 & 150 \\
\hline
\end{tabular}




\begin{tabular}{l|c|c|c|c|c|c|c|c|c|c}
\hline HPC3-SF10-NS0 & 0.35 & 10 & 0 & 334 & 37 & 0 & 963 & 989 & 2 & 160 \\
\hline HPC3-SF5-NS1.5 & 0.35 & 5 & 1.5 & 353 & 19 & 5 & 987 & 989 & 0 & 190 \\
\hline HPC3-SF0-NS3 & 0.35 & 0 & 3 & 371 & 0 & 11 & 1003 & 989 & 0 & 175 \\
\hline HPC3-SF10-NS3 & 0.35 & 10 & 3 & 334 & 37 & 10 & 964 & 989 & 0 & 220 \\
\hline
\end{tabular}

The concretes casting was defined as NBR 5738 [35] using cylindrical specimens $(10 \times 15 \mathrm{~cm})$ for each mix design. After 24 hrs. the specimens were demolded and submerged in water until they reached their ages for the mechanical tests. The ages were defined at 7 and 28 days for the compressive-strength tests (three samples for each mix proportion by age), following the criteria of NBR 5739 [36] and NBR 8522 [37], respectively. To evaluate the microstructure of the concretes at 28 days, samples of the central part of the test specimen were analyzed. For the Scanning Electron Microscopy (SEM) with Energy Dispersive X-Ray Spectroscopy (EDS) the equipment was used (Inspect F50 - FEI), operating voltage 0.3 to $30 \mathrm{kV}$ and point resolution of $1.2 \mathrm{~nm}$. The concrete samples were broken into small fragments, and sample size $0.5 \times 0.5 \mathrm{~cm}$, identified, and dried in an oven. The porosity images were captured by the microtomograph (SkyScan 1173Bruker), operating voltage of $50 \mathrm{kV}$, and electric current of $0.3 \mathrm{~mA}$, resolution of $10 \mu \mathrm{m}$ and sample size 1.0 $x 1.0 \mathrm{~cm}$. The reconstructed images edited by data viewer software, in which a sample size of $5 \times 5 \times 5$ pixels was adopted for the region of interest. CT-Vox and CT-Vol software were used to generate 3D models, and CTan software was used to calculate the porosity.

\section{RESULTS AND DISCUSSION}

\subsection{Compressive strength (fc) and elastic modulus (Ec)}

Analysis of variance (ANOVA) was used to verify if the nanosilica and silica fume content presented a statistically significant effect on the properties investigated, in which a confidence level of $95 \%$ was adopted for all analysis performed. A non-linear estimation model was developed for the compressive strength and elastic modulus from the obtained experimental data. Equations 1 and 2, respectively present the models for fc and Ec, developed through the experimental data.

$$
\begin{aligned}
& \mathrm{f}_{\mathrm{c}}=-1018.47+208.68 \times \text { Age }-338.22 \times \frac{w}{b}+4.07 \times N S-6.44 \times S F+ \\
& 26.95 \times \frac{w}{b} \times S F-5.94 \times \mathrm{Age}^{2}-0.76 \times N S^{2}, \\
& \mathrm{R}^{2}=0.89,
\end{aligned}
$$

$$
E c=65.4556-64.8823 \times \frac{w}{b}+e^{\left(0.4494 \times \frac{w}{b} \times S F\right)}+11.3464 \times \frac{w}{b} \times N S,
$$

$\mathrm{R}^{2}=0.88$.

Parameter $\mathrm{f}_{\mathrm{c}}=$ compressive strength $(\mathrm{MPa}) ; \mathrm{E}_{\mathrm{c}}=$ elastic modulus $(\mathrm{GPa}) ; \mathrm{NS}=$ nanosilica $(\%) ; \mathrm{SF}=$ silica fume $(\%)$; Age = age of samples; and $\mathrm{w} / \mathrm{b}=$ water $/ \mathrm{binder}$ ratio.

The $\mathrm{R}^{2}$ determined for each model was greater than or equal to 0.88 , meaning that the model could explain at least $88 \%$ of variability in the properties investigated. In Table 4, the ANOVA results for the models are presented. 
Table 4: ANOVA for the models.

\begin{tabular}{c|c|c|c|c|c|c}
\hline RESPONSE & SOURCE & $\begin{array}{c}\text { SUM OF } \\
\text { SQUARES }\end{array}$ & $\begin{array}{c}\text { DEGREES OF } \\
\text { FREEDOM }\end{array}$ & MEAN SQUARE & F-TEST & P-VALUE \\
\hline \multirow{2}{*}{$\mathrm{f}_{\mathrm{c}}$} & Model & 112612.1 & 8.0 & 14076.51 & 327.5529 & 0.000000 \\
& Residual & 687.6 & 16.0 & 42.97 & & \\
\hline \multirow{2}{*}{$\mathrm{E}_{\mathrm{c}}$} & Total & 113299.7 & 24.0 & & & \\
& Regression & 33879.76 & 5.0 & 6775.952 & 4511.956 & 0.000000 \\
& Residual & 10.51 & 7.0 & 1.502 & & \\
\hline
\end{tabular}

Considering the model presented in Equation 1, Figure 2 represents the effect of silica fume on the compressive strength of concretes with $3 \%$ nanosilica at 7 and 28 days for all w/b ratios investigated. The line represents the model behavior (Equation 1), and the points are the average experimental values with their standard deviation.

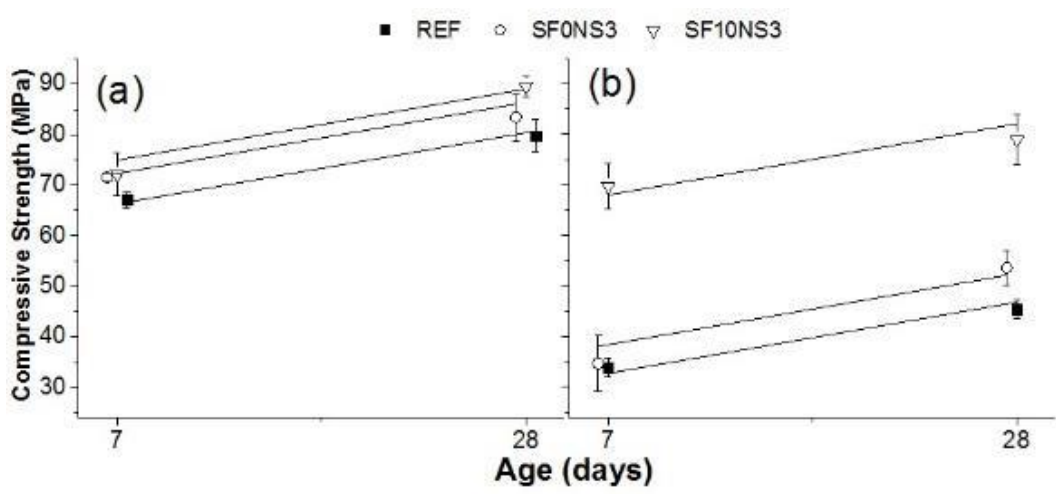

Figure 2: Effect of silica fume on the compressive strength of concretes with $3 \%$ nanosilica: (a) w/b $=0.25$ and (b) w/b = 0.35 .

Figure 3 presents the effect of nanosilica incorporation on the compressive strength of concretes with $10 \%$ silica fume for $\mathrm{w} / \mathrm{b}=0.25$ and 0.35 .

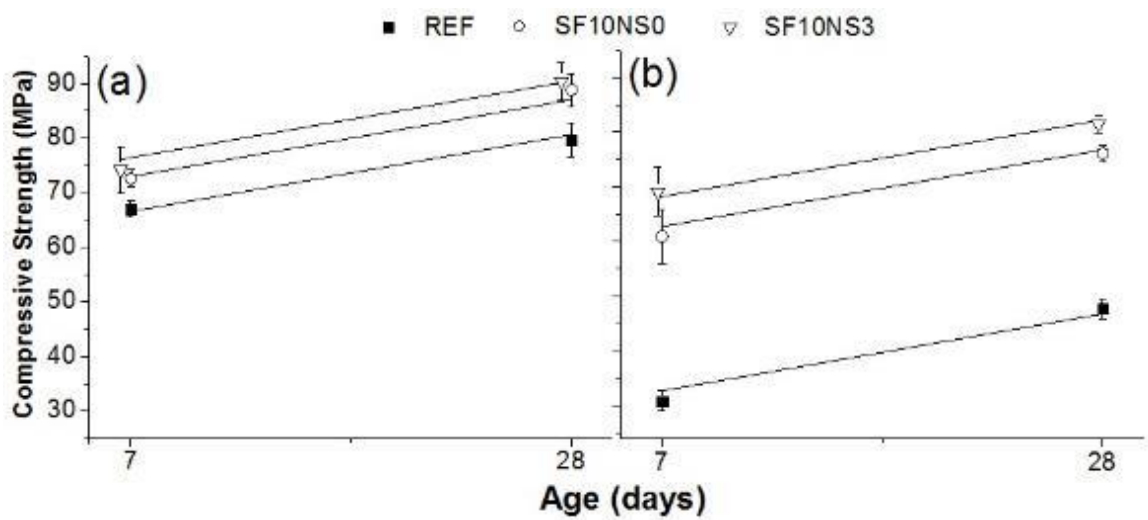

Figure 3: Effect of nanosilica on the compressive strength of concretes with $10 \%$ silica fume: $(a) w / b=0.25$ and $(b) w / b$ $=0.35$. 
An increase in the compressive strength was observed with the addition of silica fume and nanosilica in concrete, as shown in Figure 4. Compared with the reference concrete, the HPC3-SF10-NS3 showed an increased strength of $75.6 \%$ at 28 days. The concrete using only $10 \%$ silica fume (HPC3-SF10-NS0) exhibited a strength value equal to $76.75 \mathrm{MPa}, 60 \%$ higher than reference concrete $(46.79 \mathrm{MPa})$ at 28 days. These results presented similar tendencies to those obtained by ELAHI et al. [38], which found a $102 \%$ increase in the compressive strength of concrete using $7.5 \%$ silica fume at the same age. According to OLIVEIRA et al. [39] in high performance concrete the amount of silica fume present is responsible for strengthening the interfacial transition zone at the paste/aggregate, contributing to the increase in compressive strength, where the authors obtained a result of (64 and $73.4 \mathrm{MPa})$ at 28 days.

The HPC2-SF0-NS3 concrete showed an increase in compressive strength of only $8.5 \%$ when compared to the reference concrete (HPC2-SF0-NS0). When producing a high-performance concrete and when the content of nanosilica was higher, there was a higher generation of C-S-H because of its higher reactivity, allowing the hydration products to grow on their surfaces, forming a more dense C-S-H gel. However, because the addition of nanosilica can significantly increase the viscosity of the cement mixtures, a large amount of air can be trapped in the concrete, which can increase the porosity of the material [40]. According to FRAGA et al. [41] a method could be used to disperse these particles as ultrasonication and special mixers. From the ultrasonication there is a greater production of $\mathrm{C}-\mathrm{S}-\mathrm{H}$, refinement of the pores and greater compressive strength from this process, improving the effectiveness of these materials with the dis-persion of these particles.

Figure 3 shows this behavior in the HPC, although the high reactivity of the nanosilica particles increased the initial strength of the concrete, when the content of nanosilica was high, the effect did not appear as significant [22]. With the reduction in the $\mathrm{w} / \mathrm{b}$ ratio to 0.25 , the additives together did not present a significant effect. The use of $10 \%$ silica fume and $3 \%$ nanosilica resulted in a $10.5 \%$ increase in compressive strength at 28 days, compared with the reference concrete. From the results of compressive strength, it can be stated that the ideal content for the use of stabilized nanosilica is near $1.5 \%$ in concrete, optimizing the properties and providing material savings in concrete structures.

The behavior of the elastic modulus in concrete with $3 \%$ nanosilica and the addition of different amounts of silica fume can be observed in Fig. 4, whereas in Fig. 5, the effect of the addition of nanosilica on the elastic modulus of concrete with $10 \%$ silica fume is presented.

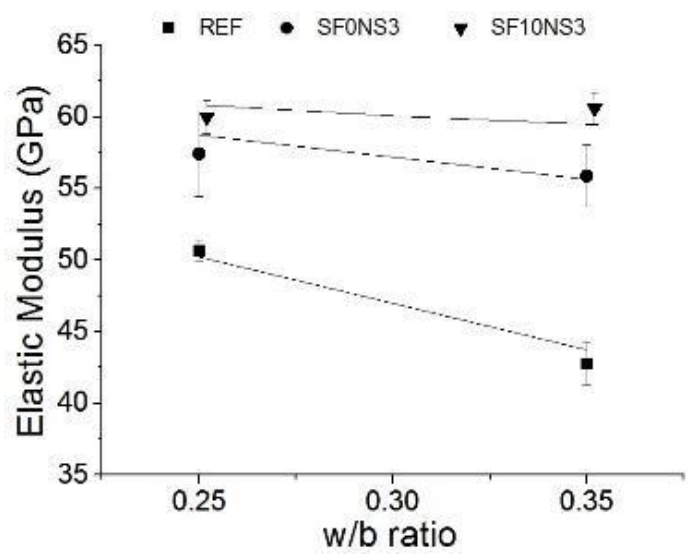

Figure 4: Effect of silica fume on the elastic modulus (Ec) of concrete with $3 \%$ nanosilica. 


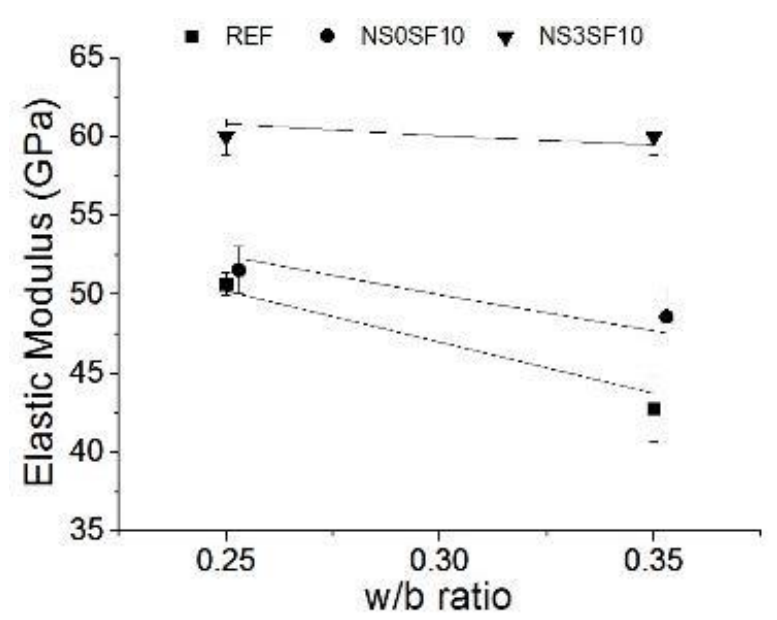

Figure 5: Effect of nanosilica on the elastic modulus (Ec) of concrete with $10 \%$ of silica fume.

The elastic modulus at 28 days increased as w/b was reduced from 0.35 to 0.25 . With the addition of $10 \%$ silica fume and $3 \%$ of nanosilica, the elastic modulus increased by $21.1 \%$ compared with the reference concrete at $\mathrm{w} / \mathrm{b}=0.25$. Meanwhile, for $\mathrm{w} / \mathrm{b}=0.30$ and 0.35 , the increases were $27.9 \%$ and $36 \%$, respectively. Piasta et al. [42] found that the elastic modulus of the high-performance concrete with w/b $=0.28$ was 47.1 $\mathrm{GPa}$, whereas the elastic modulus of the concrete with $1 \%$ nanosilica showed an increase of $13 \%$, attributed to the effects of nanosilica modification on the microstructure [19]. Because the trend of the results of both fc and Ec were consistent, that is, as the silica fume and nanosilica content were incorporated into the concretes, an improvement in the properties occurred.

\subsection{SEM with EDS and X-ray microtomography}

SEM with energy dispersive X-ray spectroscopy (EDS) analysis was used to verify the microstructure of concretes investigated and to provide a better understanding of results. The ITZ of the reference concrete Figure 1(a) presented a microstructure with $\mathrm{C}-\mathrm{S}-\mathrm{H}$ predominance and high porosity and voids. According to the EDS results presented in Figure 6(b), a large amount of $\mathrm{Ca}$ and small peaks of $\mathrm{C}$, O, and Si can be observed.

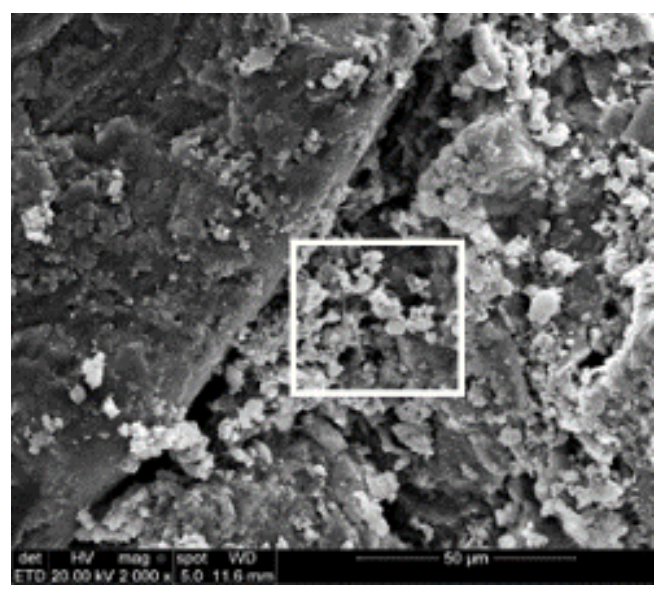

(a)

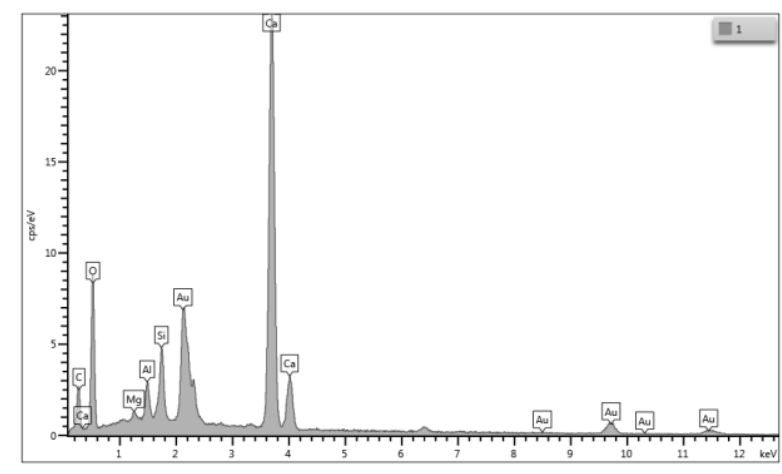

(b)

Figure 6: SEM for concrete (a) HPC3-SFO-NS0, (b) EDS of highlight area.

Figure 7(a) reveals that the concrete paste contained possible C-S-H with dense structure with the presence of gel pores between the C-S-H layers. These results are similar to those found by JI [43], JO et al. [44], YU et al. [40], and DU et al. [45], who demonstrated the performance of nanosilica in the refinement of cement paste. Analyzing the EDS of Figure 7(b), the presence of calcium-dominated element peaks and 
smaller amounts of $\mathrm{Si}, \mathrm{Ca}$, and $\mathrm{O}$ were observed. According to JALAL et al. [31] the significant increase in compressive strength with silica fume and nanosilica was caused by the rapid consumption of $\mathrm{CH}$ produced during Portland-cement hydration, especially in the early ages, related to the high reactivity of particles. Therefore, the hydration of the cement was accelerated, and larger volumes of hydrated products were formed.

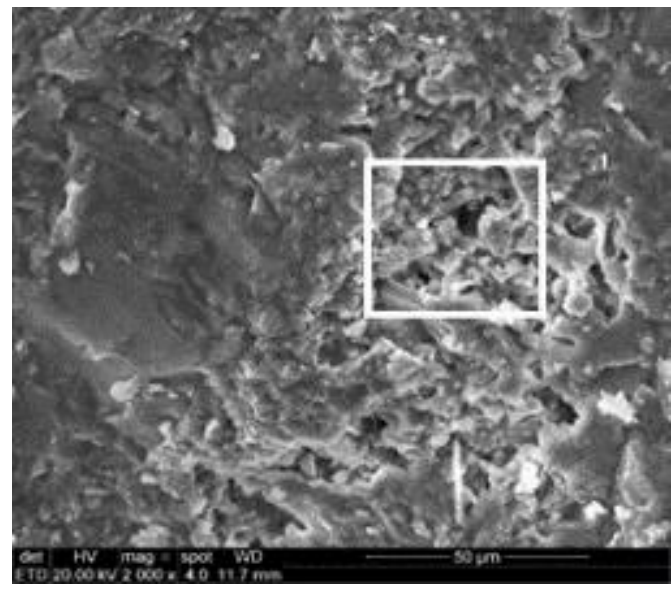

(a)

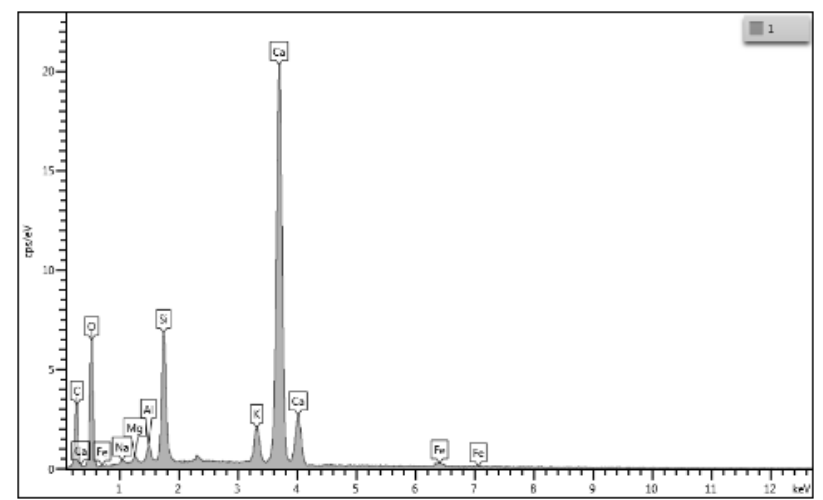

(b)

Figure 7: SEM for (a) concrete HPC3-SF10-NS3; (b) EDS of highlight area.

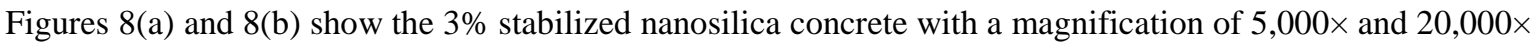
respectively. A predominance of $\mathrm{CH}$ crystals, ettringite, and more porous cementitious pastes are observed with pores in the regions around $\mathrm{CH}$ and ettringite. The images confirm the results of the compressive strength, because the nanosilica for this content did not present an increase in resistance as high as the silica fume used in an isolated manner. According to KHALOO et al. [30], the nanosilica particles presented a high specific surface area, which could result in a greater possibility of forming agglomerates of nanoparticles, affecting the efficiency of nanosilica, particularly thinner and more reactive grains.

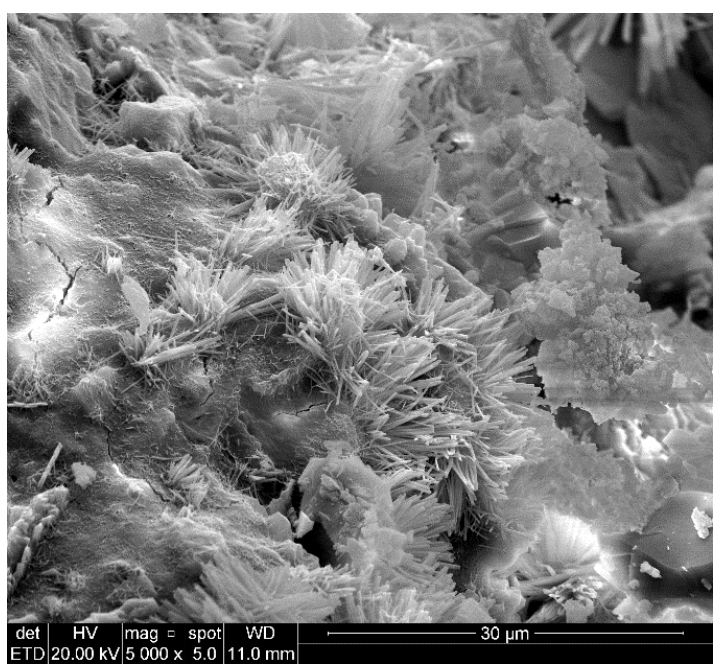

(a)

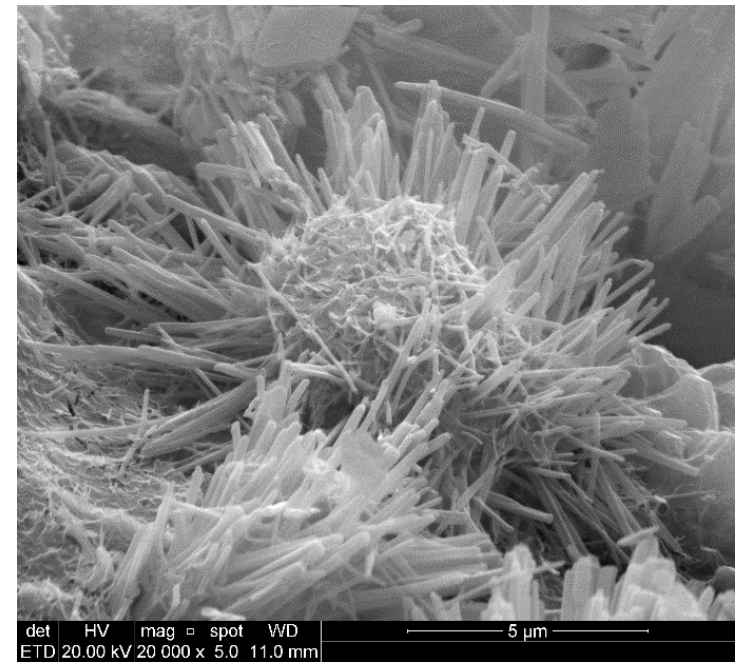

(b)

Figure 8: SEM for concrete with $w / b=0.35$ and 3\% nanosilica: (a) magnification 5,000x, (b) magnification 20,000x.

Figure 9(a) shows the presence of a predominantly C-S-H region, because the predominant Si peaks and, in smaller amounts, Al, O, and Ca peaks (Fig. 9b) are characteristic of exclusively nanosilica concretes. 
However, the microstructure of concrete with silica fume presented a similar morphology (Figure 10a). Figure $10 \mathrm{~b}$ shows the presence of silicon peaks and lower proportions of $\mathrm{O}$ and $\mathrm{Ca}$. The presence of the $\mathrm{Al}$ peak must be related to the presence of aluminosilicate compound.

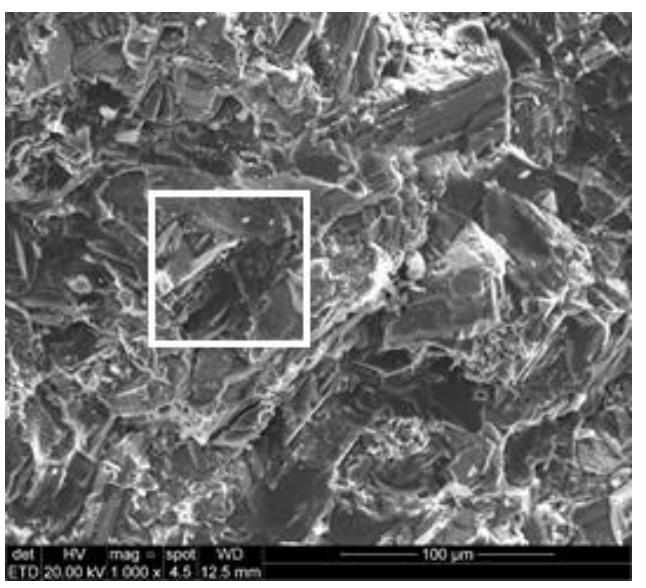

(a)

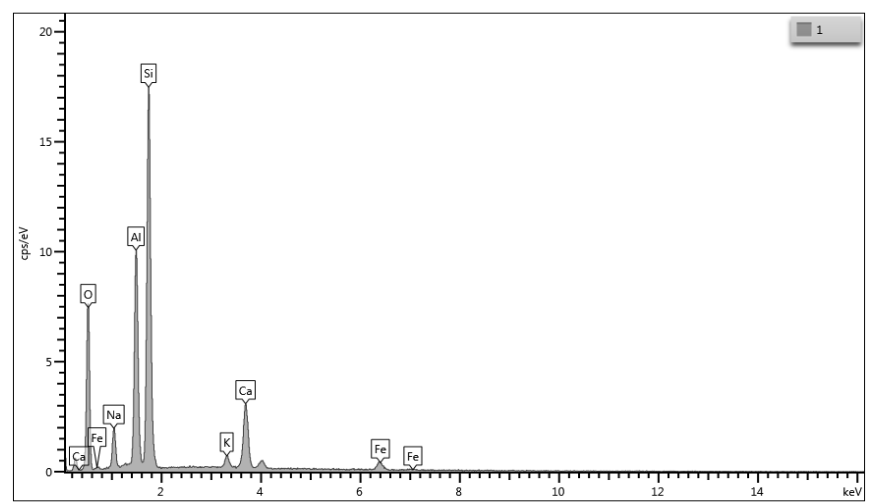

(b)

Figure 9: SEM for (a) concrete HPC1-SF0-NS3, (b) EDS of highlight area

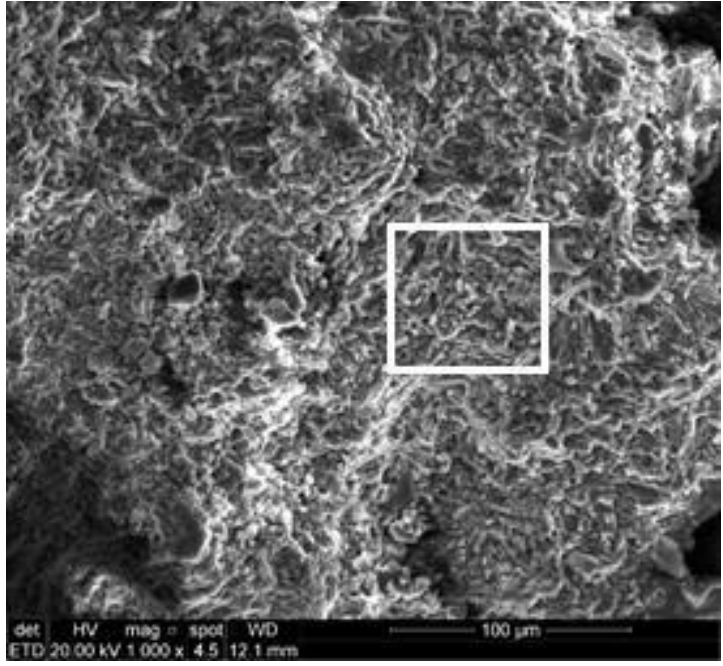

(a)

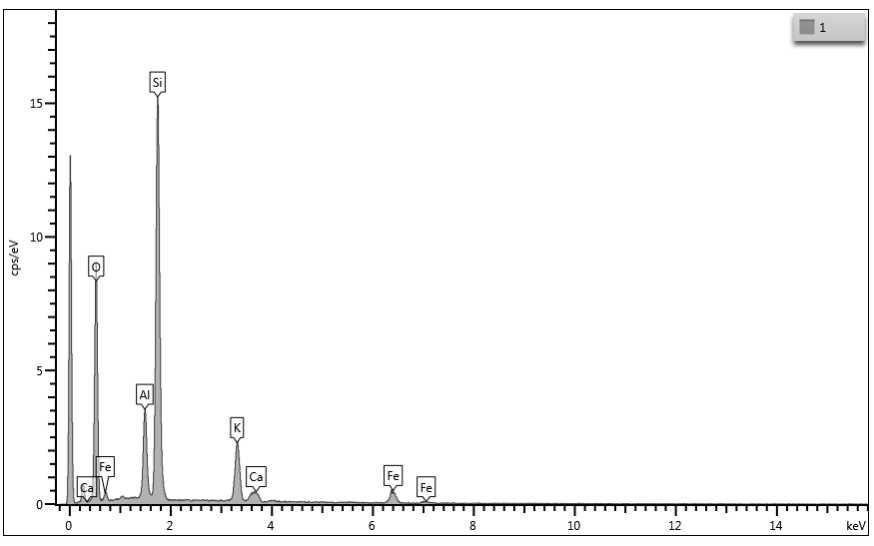

(b)

Figure 10: SEM for (a) concrete HPC1-SF10-NS0, (b) EDS of highlight area.

Generally, it can be inferred that the variable influencing concrete densification the most is the w/b ratio, followed by the number of mineral admixtures. There is a direct correlation between the results obtained through macro-structural analysis and the microstructural investigations. In the case of $w / b=0.35$, for example, as the silica fume content increased, there was an increase in the compressive strength of the concretes. However, SEM analysis showed the predominance of C-S-H with dense structure. Because of its fineness and high content of amorphous silicon dioxide, silica fume is a very reactive pozzolanic material, which, upon reaction, decreases and modifies the orientation of $\mathrm{CH}$ crystals [46]. Additionally, silica-fume particles filled the spaces between the grains of cement, resulting in a more homogeneous cementitious matrix and transition zone. Figures 11, 12, 13 show the reconstructed images and porosities obtained from X-ray microtomography, indicating that the light-gray region corresponds to the large aggregate, whereas the dark gray portion corresponds to the cementitious paste. The circular points represent the pores. The images were reconstructed in cubic samples of $5 \times 5 \times 5$ pixels. The heterogeneous microstructure of the material and the phases (i.e., aggregates, paste, and pores) are clearly perceived, and the results of the figures are similar to 
those obtained by Chung et al. [47], where the authors showed the distribution of the voids and the constituents of the concrete.
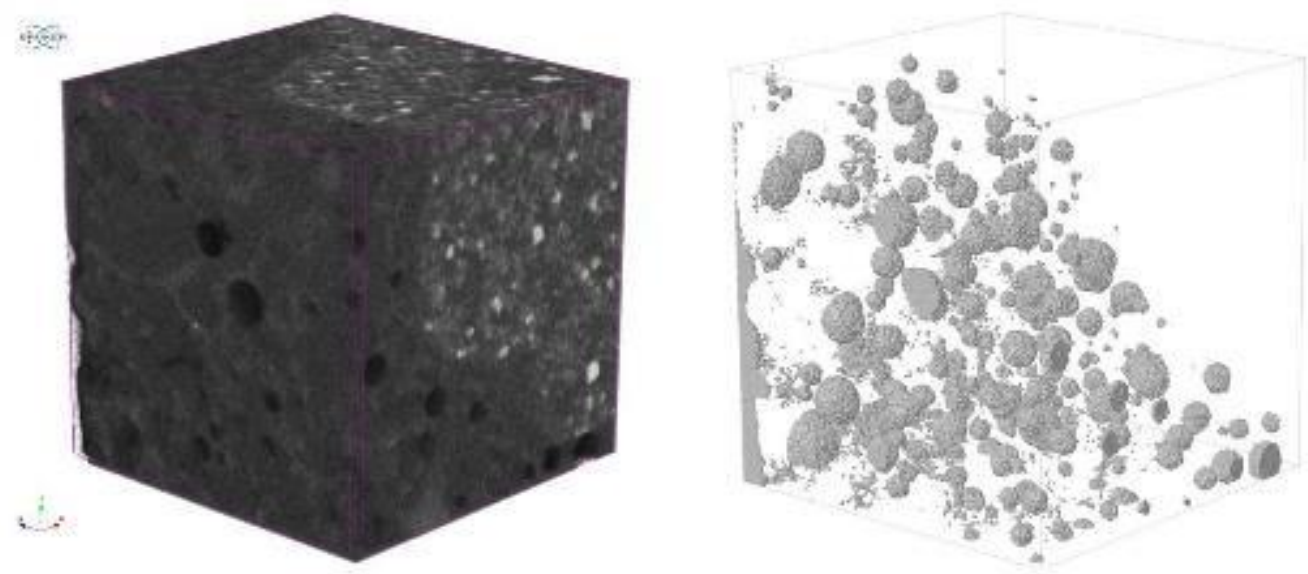

Figure 11: Reconstructed image and pores of reference concrete with $w / b=0.35$.
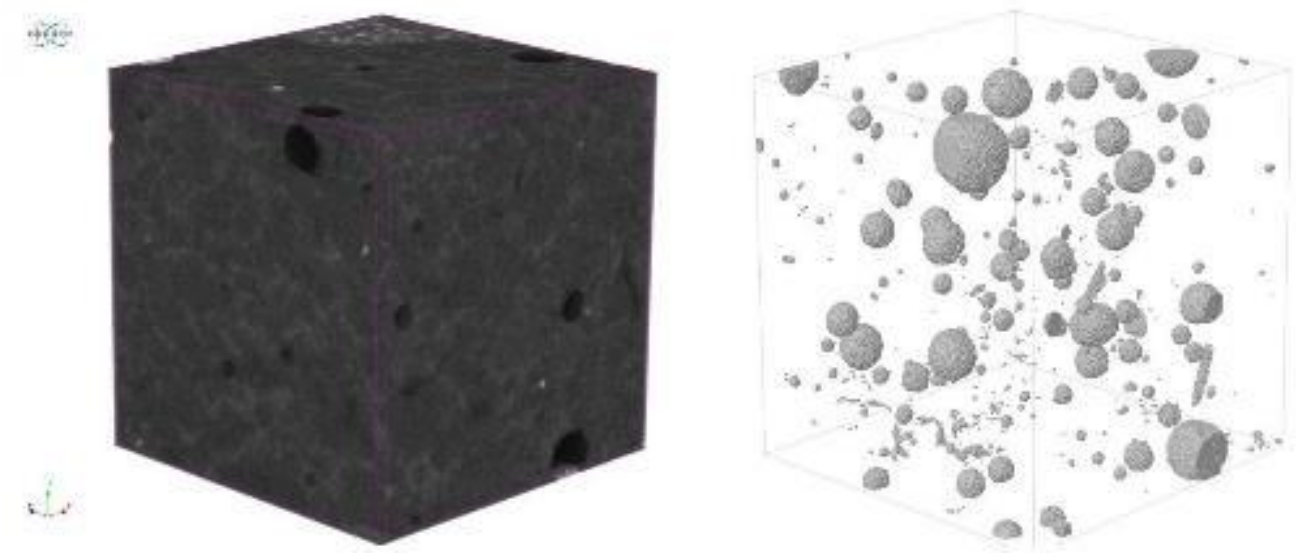

Figure 12: Reconstructed image and concrete pores with $10 \%$ silica fume and $w / b=0.35$.
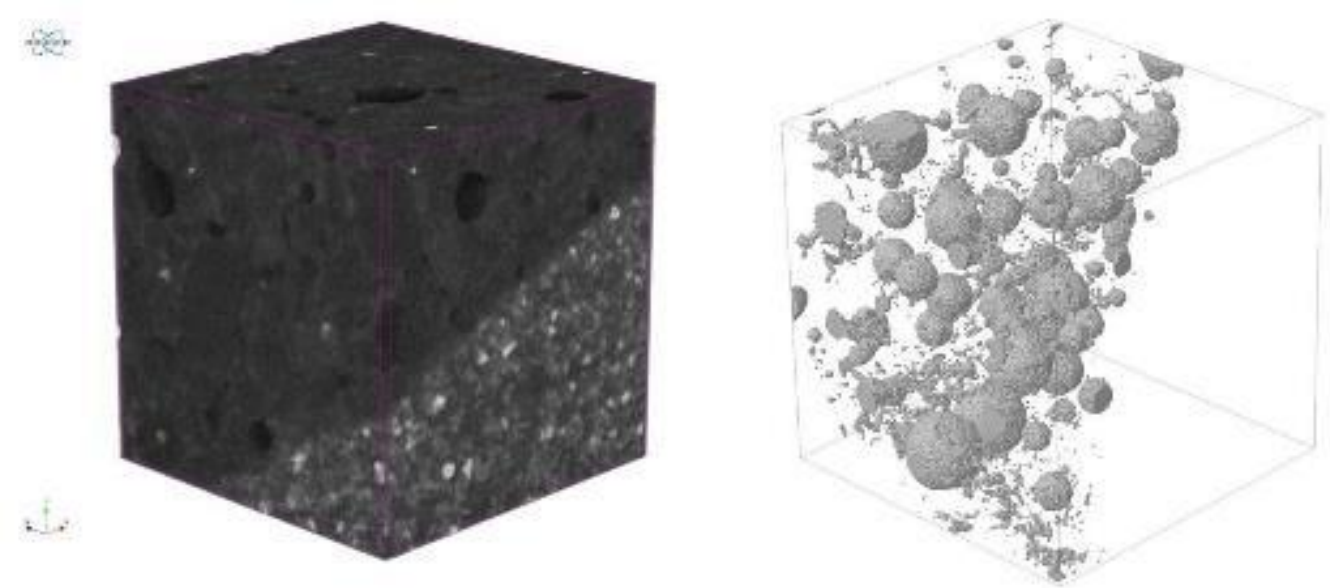

Figure 13: Reconstructed image and pores of concrete with $3 \%$ nanosilica and $w / b=0.35$

The percentage of white pixels, in relation to the total pixels of the image, yields the porosity calculation. All 
pores are considered open and closed according to the selected volume of interest. The results, shown in Fig. 14, show that the reference concrete at $3.99 \%$ exhibited the highest porosity. From the three analyses, the sample with silica fume exhibited the lowest porosity, 3.27\%, whereas nanosilica had a porosity of $3.78 \%$. These values were similar to those found by Lu et al. [48], who found a decrease in porosity values of $6.2 \%$ for the reference concrete and $6 \%$ for the concrete with $7 \%$ silica fume.

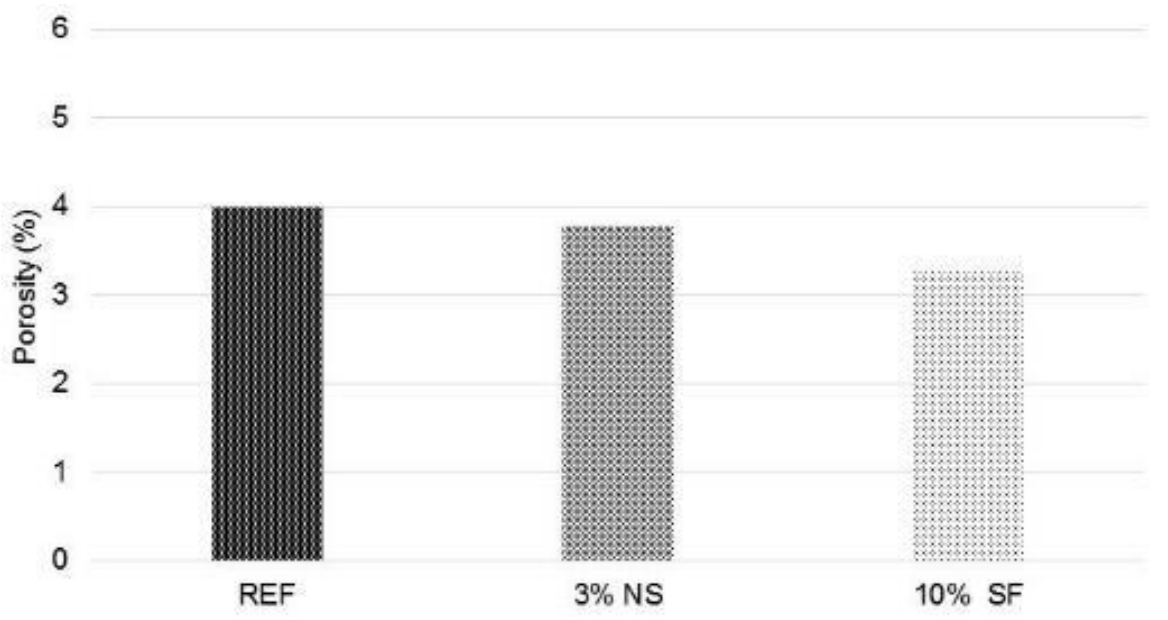

Figure 14: Total porosity of samples $(\%)$ obtained by X-ray microtomography for concretes with w/b $=0.35$.

Using X-ray micro tomography, it was verified that it is possible to obtain images showing the porosity of the concretes. However, the samples need to be smaller to increase the resolution of the images, as reported by Leite and Monteiro [49]. Additionally, the values obtained by the CTan software reiterate the results of the mechanical tests, in which the use of silica fume promotes the reduction of porosity. The silica particles react with the $\mathrm{CH}$, forming additional phases, such as low- and high-density $\mathrm{C}-\mathrm{S}-\mathrm{H}$. Unreacted silica particles act as filler, reducing the porosity of the concrete matrix [50]. According to the compressive strength (fc) and elastic modulus (Ec) results, silica fume provided a significant difference when compared to nanosilica in concrete porosity. However, according to Feng et al. [24] comparing the reference sample and the nanosilica sample both have very similar volume fractions of gel pores and medium capillary pores. This factor was explained by the possible agglomeration of nanosilica and the compact gel structure of hydration products, the diffusion of unhydrates is blocked and thus produces a more porous structure.

\section{CONCLUSIONS}

The high-performance concretes composed some combinations such superplasticizer additive with colloidal nanosilica suspension and slurried silica fume in was studied in this work. The focus on materials and test procedures per-formed in this investigation demonstrated that:

High-performance concrete containing silica fume exhibited higher compressive strength and elastic modulus results than mixtures using only stabilized nanosilica for all investigated $\mathrm{w} / \mathrm{b}$.

The results of concrete using only $10 \%$ silica fume and w/b 0.35 showed an increased strength of $47 \%$ (76.75 MPa) than stabilized nanosilica concrete (at 52.19 MPa) age 28 days. The elastic modulus HPC3SF10-NS3 increased by 36\% compared with the reference concrete.

According to the microstructure investigation, the concretes with the simultaneous combination nanosilica and silica fume presented a dense and uniform microstructure, with a predominance of C-S-H particles, related to the synergistic effect.

The HPC containing only polycarboxylate superplasticizer with nano- $\mathrm{SiO}_{2}$ presents of $\mathrm{CH}$ crystals, ettringite, and more pores in the regions around $\mathrm{CH}$ and ettringite. The x-ray micro tomography images showed a porosity similar to high-performance concrete without nanosilica.

The silica fume and nanosilica incorporation in any levels promotes an increase in the hydration of the paste, increasing the amount of additional $\mathrm{CSH}$. Based on the results, verified an increase of microstructural densification of cement matrix, with the minimization of interfacial transition zone. 


\section{ACKNOWLEDGMENTS}

This study was financed in part by the Coordenação de Aperfeiçoamento de Pessoal de Nível Superior - Brasil (CAPES) - Finance Code 001. The authors would like to thank the Central Laboratory of Microscopy and Microanalysis, Materials Laboratory, and the Institute of Petroleum and Natural Resources (IPR) located at PUCRS. We would also like to thank Mr. Airton Silva from the Laboratory of Materials and Technology of the Built Environment of Federal University of Rio Grande do sul (NORIE/UFRGS).

\section{BIBLIOGRAFHY}

[1] NICOARA, A.I., STOICA, A.E., VRABEC, M., et al. "End-of-Life Materials Used as Supplementary Cementitious Materials in the Concrete Industry", Materials, v.13, n.8, 2020.

[2] NEHDI, M.L. "Only tall things cast shadows: Opportunities, challenges and research needs of selfconsolidating concrete in super-tall buildings", Construction and Building Materials, v. 48, p. 80-90, 2013.

[3] PEREIRO-BARCELÓ, J., BONET, J.L., GÓMEZ-PORTILLO, S., et al. "Ductility of high-performance concrete and very-high-performance concrete elements with Ni-Ti reinforcements", Construction and Building Materials, v.175, p. 531-551, 2018.

[4] HEMALATHA, M.S., SANTHANAM, M. "Characterizing supplementary cementing materials in blended mortars", Construction and Building Materials, v. 191, p. 440-459, 2018.

[5] SKIBSTED, J., SNELLINGS, R. "Reactivity of supplementary cementitious materials (SCMs) in cement blends", Cement and Concrete Research, v. 124, n. 105799, 2019.

[6] LU, D., TANG, Z., ZHANG, L., et al. "Effects of Combined Usage of Supplementary Cementitious Materials on the Thermal Properties and Microstructure of High-Performance Concrete at High Temperatures", Materials, v. 13, n. 8, 2020.

[7] NORHASRI, M.S.M., HAMIDAH, M.S., FADZIL, A.M. "Applications of using nano material in concrete: A review", Construction and Building Materials, v. 133, p. 91-97, 2017.

[8] LOTHENBACH, B., SCRIVENER, K., HOOTON, R. D. "Supplementary cementitious materials", $\mathrm{Ce}$ ment and Concrete Research, v. 41, p. 1244-1256, 2011.

[9] MAZLOOM, M., RAMEZANIANPOUR, A.A., BROOKS, J.J. "Effect of silica fume on mechanical properties of high-strength concrete", Cement and Concrete Composites, v. 26, p. 347-357, 2004.

[10] VÁZQUEZ-RODRÍGUEZ, F.J., ELIZONDO-VILLAREAL, N., VERÁSTEGUI, L.H., et al. "Effect of Mineral Aggregates and Chemical Admixtures as Internal Curing Agents on the Mechanical Properties and Durability of High-Performance Concrete", Materials, v. 13, n.9, 2020.

[11] SIDDIQUE, R., CHAHAL, N. "Use of silicon and ferrosilicon industry by-products (silica fume) in cement paste and mortar", Resources, Conservation \& Recycling, p. 739-744, 2011.

[12] ANWAR, M., EMARAH, D.A. "Resistance of concrete containing ternary cementitious blends to chloride attack and carbonation", Journal of Materials Research and Technology, 2020.

[13] CHUNG, S.Y., KIM, J., LEHMANN, C., et al. "Investigation of phase composition and microstructure of foamed cement paste with different supplementary cementing materials", Cement and Concrete Composites. v. 109, n.103560, 2020.

[14] MEHTA, A., ASHISH, D. K. "Silica fume and waste glass in cement concrete production: A review", Journal of Building Engineering, v. 29, n.100888, 2020.

[15] TAYLOR, H.F.W., Cement Chemistry, 2nd ed., London, Thomas Telford, 1997.

[16] BAUTISTA-GUTIERREZ, K.P., HERRERA-MAY, A.L., SANTAMARÍA-LÓPEZ, J.M., et al. "Recent Progress in Nanomaterials for Modern Concrete Infrastructure: Advantages and Challenges", Materials, v. 12, n.21, 2019.

[17] XU, G., SHI, X. "Characteristics and applications of fly ash as a sustainable construction material: A state-of-the-art review", Resources, Conservation \& Recycling, v. 136, p. 95-109, 2018.

[18] SAID, A.M., ZEIDAN, M.S., BASSUONI, M.T., et al. "Properties of concrete incorporating nanosilica", Construction and Building Materials, v. 36, p. 838-844, 2012.

[19] XU, J., WANG, B., ZUO, J. "Modification effects of nanosilica on the interfacial transition zone in con- 
crete: A multiscale approach", Cement and Concrete Composites, v.81, p. 1-10, 2017.

[20] NAZERIGIVI, A., NAJIGIVI, A. "Study on mechanical properties of ternary blended concrete containing two different sizes of nano-SiO ${ }_{2}$ ", Composites Part B: Engineering, v. 167, p. 20-24, 2019.

[21] LI, G., GAO, B. "Effect of level $\mathrm{SiO}_{2}$ and level $\mathrm{CaCO}_{3}$ on concrete performance", Journal of Railway Engineering Society, v. 28, p. 131-136, 2006.

[22] NILI, M., EHSANI, A. "Investigating the effect of the cement paste and transition zone on strength development of concrete containing nanosilica and silica fume", Materials \& Design, v. 75, p. 174-83, 2015.

[23] WANG, L., ZHENG, D., ZHANG, S., et al. "Effect of Nano-SiO ${ }_{2}$ on the Hydration and Microstructure of Portland cement", Nanomaterials, v.6, n.12, 2016.

[24] FENG, P., CHANG, H., LIU, X., et al. "The significance of dispersion of nano-SiO ${ }_{2}$ on early age hydration of cement pastes", Materials \& Design, v. 186, 2020.

[25] SUN, D., WU, K., SHI, H., et al. "Effect of interfacial transition zone on the transport of sulfate ions in concrete", Construction and Building Materials, v. 192, p. 28-37, 2018.

[26] AMERICAN SOCIETY FOR TESTING AND MATERIALS. ASTM. Standard Specification for Portland cement. West Conshohocken, PA: American Society for Testing and Materials, 2004.

[27] ASSOCIAÇÃO BRASILEIRA DE NORMAS TÉCNICAS. NBR NM 52. Fine aggregate - Determination of specific gravity and apparent specific mass, Rio de Janeiro, 2009.

[28] ASSOCIAÇÃO BRASILEIRA DE NORMAS TÉCNICAS. NBR NM 45. Aggregates - Determination of the unit weight and air-void contents, Rio de Janeiro, 2006.

[29] ASSOCIAÇÃO BRASILEIRA DE NORMAS TÉCNICAS. NBR NM 248. Aggregates - Sieve analysis of fine and coarse aggregates, Rio de Janeiro, 2003.

[30] KHALOO, A., MOBINI, M.H., HOSSEINI, P. "Influence of different types of nano-SiO $\mathrm{S}_{2}$ particles on properties of high-performance concrete", Construction and Building Materials, v.113, p. 188-201, 2016.

[31] JALAL, M., POULADKHAN, A., HARANDI, O.F., et al. "Comparative study on effects of Class F fly ash, nano silica and silica fume on properties of high performance self-compacting concrete", Construction and Building Materials, v. 94, p. 90-104, 2015.

[32] SILVA, S.R., ANDRADE, J.J.O. "Investigation of mechanical properties and carbonation of concretes with construction and demolition waste and fly ash", Construction and Building Materials, v. 153, p. 704-15, 2017.

[33] CABRAL, A.E.B., SCHALCH, V., MOLIN, D.C.C.D., et al. "Mechanical properties modeling of recycled aggregate concrete", Construction and Building Materials, v. 24, p. 421-30, 2010.

[34] AÏTCIN, P.C., Concreto de Alto Desempenho, São Paulo, PINI, 2000.

[35] ASSOCIAÇÃO BRASILEIRA DE NORMAS TÉCNICAS. NBR 5738. Procedure for molding and curing concrete test specimens, Rio de Janeiro, 2016.

[36] ASSOCIAÇÃO BRASILEIRA DE NORMAS TÉCNICAS. NBR 5739. Concrete - Compression test of cylindrical specimens, Rio de Janeiro, 2018.

[37] ASSOCIAÇÃO BRASILEIRA DE NORMAS TÉCNICAS. NBR 8522. Concrete - Determination of static modulus of elasticity and deformation by compression, Rio de Janeiro, 2017.

[38] ELAHI, A., BASHEER, P.A.M, NANUKUTTAN, S.V., et al."Mechanical and durability properties of high performance concretes containing supplementary cementitious materials", Construction and Building Materials, v. 24, n. 3, p. 292-299, 2010.

[39] OLIVEIRA, C.O., MACIEL, G.D.F., DE CASTRO, A.L., et al. "Impacto do conceito de empacotamento de partículas na dosagem de concretos de alto desempenho", Matéria (Rio J.) [online], v. 23, n. 1, 11962, 2018.

[40] YU, R., TANG, P., SPIESZ, P., et al. "A study of multiple effects of nano-silica and hybrid fibres on the properties of Ultra-High Performance Fibre Reinforced Concrete (UHPFRC) incorporating waste bottom ash (WBA)", Construction and Building Materials, v. 60, p. 98-110, 2014.

[41] FRAGA, Y.S.B., REGO, J.H.S., CAPUZZO, V.M.S., et al. "Efeito da ultrasonicação da sílica ativa e da nanossílica coloidal em pastas de cimento", Matéria (Rio J.) [online], v. 25, n.4, 12847, 2020. 
[42] PIASTA, W., GÓRA, J., BUDZYŃSKI, W. "Stress-strain relationships and modulus of elasticity of rocks and of ordinary and high performance concretes", Construction and Building Materials, v. 153, p. 728 $739,2017$.

[43] JI, T. "Preliminary study on the water permeability and microstructure of concrete incorporating nano$\mathrm{SiO}_{2}$ ", Cement and Concrete Research, v. 35, p. 1943-1947, 2005.

[44] JO, B.W., KIM, C.H., TAE, G.H., et al. "Characteristics of cement mortar with nano-SiO2 particles", Construction and Building Materials. v. 21, p. 1351-1355, 2007.

[45] DU, H., DU, S., LIU, X. "Durability performances of concrete with nano-silica", Construction and Building Materials, v.73, p. 705-712, 2014.

[46] KHAN, M.I, SIDDIQUE, R. "Utilization of silica fume in concrete: Review of durability properties", Resources, Conservation \& Recycling, v. 57, p. 30-35, 2011.

[47] CHUNG, S.Y., ELRAHMAN, M.A., Stephan, D. "Investigation of the effects of anisotropic pores on material properties of insulating concrete using computed tomography and probabilistic methods", Energy and Buildings, v.125, p. 122-129, 2016.

[48] LU, S., LANDIS, E.N., KEANE, D.T. "X-ray microtomographic studies of pore structure and permeability in Portland cement concrete", Materials and Structures, v. 39, p. 611-620, 2006.

[49] LEITE, M.B., MONTEIRO, P.J.M. "Microstructural analysis of recycled concrete using X-ray micro tomography", Cement and Concrete Research, v. 81, p. 38-48, 2016.

[50] MADDALENA, R., HAMILTON, A. "Low-pressure silica injection for porosity reduction in cementitious materials", Construction and Building Materials, v. 134, p. 610-616, 2017.

\section{ORCID}

Jéssica Zamboni Schiavon Pietra Moraes Borges Sérgio Roberto da Silva Jairo José de Oliveira Andrade https://orcid.org/0000-0001-9156-2794

https://orcid.org/0000-0003-3152-6569

https://orcid.org/0000-0002-9843-002X

https://orcid.org/0000-0003-2073-6763 